\title{
EFEKTIVITAS PENERAPAN SASARAN KINERJA PEGAWAI (SKP)-ONLINE DI LINGKUNGAN BIRO UMUM SEKRETARIAT DAERAH PROVINSI JAMBI
}

\author{
Oleh
}

\author{
Nila Apriani ${ }^{1}$, \\ Ngadisah $^{2}$, Sampara Lukman ${ }^{3}$ \\ 1) Pemerintah Provinsi Jambi \\ Program Magister Terapan Studi Pemerintahan Daerah Institut Pemerintahan Dalam Negeri \\ nilaapriani1004@gmail.com \\ 2,3) Institut Pemerintahan Dalam Negeri
}

\begin{abstract}
$T$ The focus of this research is to look the effectiveness of the implementation of Employee Performance Targets (SKP)-Online in the General Bureau of the Regional Secretariat of Jambi Province, inhibiting factors and the efforts made in implementing SKP-Online to optimally improve the performance of state civil servants in the General Bureau of the Regional Secretariat of Jambi Province. The research uses theory by Gibson, Donnelly, and Ivancevich related to organizational effectiveness, then limited to the application of SKP-Online and employee behaviour. This research uses a qualitative method with a descriptive approach. In collecting data, researcher conducted observations, interviews and collected documents related to the application of SKP-Online in the General Bureau of the Regional Secretariat of Jambi Province. The results showed that the application of SKP-Online in the General Bureau of the Regional Secretariat of Jambi Province had not been going well and optimally, it can be seen from the implementation and the supervision process and the attitude shown by the employee performance tergets (SKP)-Online. Then a less productive work environment and less competent apparatus resources as well as a sense of employee responsibility for their duties and functions as state civil servants. Efforts made to improve employee performance in the application of SKP-Online include: 1. Creating an innovation by forming a group of employees in one "Whatsapp" application; 2. Conducting socialization again to all employees and informing about the SKP-Online operation tutorial; 3. Motivating employees to learn how to use technology facilities. But these have not shown significant results so that other efforts are needed to improve employee performance so that the implementation of SKP-Online can run optimally.
\end{abstract}

Keywords: effectiveness, SKP-online, employee performance.

\section{Abstrak}

$\mathrm{F}$ okus dari penelitian ini adalah melihat efektivitas penerapan Sasaran Kinerja Pegawai (SKP)Online di Lingkungan Biro Umum Sekretariat Daerah Provinsi Jambi, faktor penghambat serta upaya yang dilakukan dalam penerapan SKP-Online untuk meningkatkan kinerja aparatur sipil negara secara optimal di Lingkungan Biro Umum Sekretariat Daerah Provinsi Jambi. Penelitian menggunakan teori oleh Gibson, Donnelly, dan Ivancevich terkait efektivitas organisasi, kemudian dibatasi pada penerapan SKP-Online dan perilaku pegawai. Penelitian 
ini menggunakan metode kualitatif dengan pendekatan deskriptif. Dalam mengumpulkan data, peneliti melakukan observasi, wawancara dan mengumpulkan dokumen yang terkait dalam penerapan SKP-Online di lingkungan Biro Umum Sekretariat Daerah Provinsi Jambi. Hasil penelitian menunjukkan bahwa penerapan SKP-Online di lingkungan Biro Umum Sekretariat Daerah Provinsi Jambi belum berjalan dengan baik dan optimal, terlihat dari proses pelaksanaannya dan pengawasan dalam penerapan sasaran kinerja pegawai (SKP)-Online. Kemudian lingkungan kerja yang kurang produktif dan sumber daya aparatur yang masih kurang kompeten serta rasa tanggung jawab pegawai terhadap tugas dan fungsinya sebagai aparatur sipil negara. Upaya yang dilakukan untuk meningkatkan kinerja pegawai dalam penerapan SKP-Online antara lain: 1. Membuat suatu inovasi dengan membentuk grup pegawai dalam satu aplikasi "Whatsapp"; 2. Melakukan sosialisasi kembali kepada seluruh pegawai dan menginformasikan adanya tutorial pengoperasian SKP-Online; 3. Memotivasi pegawai agar mau belajar cara penggunaan sarana teknologi. Akan tetapi upaya tersebut masih belum menunjukkan hasil yang signifikan sehingga perlu adanya upaya lain dalam meningkatkan kinerja pegawai agar penerapan SKP-Online dapat berjalan secara optimal.

Kata kunci: efektivitas, SKP-online, kinerja pegawai

\section{PENDAHULUAN}

$\mathrm{P}$ erkembangan zaman yang terjadi di dunia sangat berpengaruh kepada dunia instansi pemerintahan. Di instansi pemerintahan, dalam rangka usaha untuk lebih menjamin objektivitas dalam pembinaan pegawai negeri sipil berdasarkan sistem karier dan sistem prestasi kerja, maka diadakan penilaian pekerjaan Pegawai Negeri Sipil. Di mana Sebelumnya penilaian prestasi kerja Pegawai Negeri Sipil diatur pada Peraturan Pemerintah Republik Indonesia Nomor 10 Tahun 1979 tentang Penilaian Pelaksanaan Pekerjaan Pegawai Negeri Sipil dalam bentuk Daftar Penilaian Pelaksanaan Pekerjaan Pegawai Negeri Sipil atau disebut DP3 PNS.

Seiring berjalannya waktu, DP3 kemudian disempurnakan dengan menggunakan sasaran kerja pegawai atau disebut dengan SKP pegawai negeri sipil. SKP telah diatur sedemikian rupa di dalam Peraturan Pemerintah Republik Indonesia Nomor 46 Tahun 2011 tentang Penilaian Prestasi Kerja Pegawai Negeri Sipil, dengan regulasinya yang diatur dalam Peraturan
Badan Kepegawaian Negara Nomor 1 Tahun 2013 tentang Ketentuan Pelaksanaan Peraturan Pemerintah Nomor 46 Tahun 2011 tentang Penilaian Prestasi Kerja Pegawai Negeri Sipil, yang menjadi pedoman bagi pejabat yang menilai atau pegawai negeri sipil dalam melaksanakan ketentuan penilaian prestasi PNS.

Ketentuan penilaian prestasi kerja pegawai memiliki standar dari Bobot nilai SKP 60\% dan Perilaku Kerja memiliki bobot $40 \%$. Sasaran kinerja pegawai adalah target dan rencana pegawai yang ingin dicapai individu pegawai tersebut, yang disusun dan disepakati oleh pegawai dan atasannya. Perilaku kerja merupakan suatu sikap, tingkah laku, perbuatan yang diperbuat oleh seorang pegawai negeri atau tidak melakukan sesuatu perbuatan yang seharusnya dilakukan oleh seorang pegawai berdasarkan dengan ketentuan peraturan perundang-undangan. Peralihan DP3 menjadi SKP diharapkan penilaian pegawai dapat dilakukan dengan target-target yang lebih jelas dan terukur, di mana SKP disusun dan disepakati oleh pegawai dan atasannya, serta dilaksanakan oleh pejabat penilai setiap satu tahun sekali baik pada akhir tahun ataupun januari pada berikutnya. 
Tabel 1 Daftar Pegawai di Lingkungan Biro Umum Setda Provinsi Jambi

\begin{tabular}{|c|c|c|c|c|c|c|c|c|c|c|c|c|c|c|c|c|c|}
\hline \multirow[b]{2}{*}{ No } & \multirow[b]{2}{*}{ Jabatan } & \multicolumn{3}{|c|}{ Eselon } & \multicolumn{5}{|c|}{ Usia } & \multicolumn{7}{|c|}{ Pendidikan } & \multirow[b]{2}{*}{ JML } \\
\hline & & IIb & IIIa & IV & $\begin{array}{c}20- \\
30\end{array}$ & $\begin{array}{c}31- \\
40\end{array}$ & $\begin{array}{c}41- \\
45\end{array}$ & $\begin{array}{c}45- \\
50\end{array}$ & $\begin{array}{c}51- \\
58\end{array}$ & S3 & S2 & S1 & D3 & SLTA & SLTP & SD & \\
\hline 1. & $\begin{array}{l}\text { K e p a l a } \\
\text { Biro }\end{array}$ & 1 & - & - & - & - & - & - & 1 & - & - & 1 & - & - & - & - & 1 \\
\hline 2. & $\begin{array}{l}\text { K e p a l a } \\
\text { Bagian }\end{array}$ & - & 3 & - & - & - & 2 & - & 1 & - & 2 & 1 & - & - & - & - & 3 \\
\hline 3. & Kasubbag & - & - & 9 & - & 2 & 4 & 1 & 2 & - & 4 & 5 & - & - & - & - & 9 \\
\hline 4. & Staf & - & - & - & 8 & 22 & 20 & 29 & 32 & - & 5 & 44 & 3 & 51 & 5 & 2 & 111 \\
\hline \multicolumn{17}{|c|}{ Jumlah Total } & 124 \\
\hline
\end{tabular}

Sumber: Biro Umum Setda Provinsi Jambi 2019

Pada 2014 penyelenggaraan pemerintahan di Indonesia mengatur kembali kebijakan pemerintahan daerah melalui Undang-Undang Nomor 23 Tahun 2014 tentang Pemerintahan Daerah. Dalam peraturan tersebut menjelaskan bahwa daerah merupakan perpanjangan tangan dari penyelenggaraan pemerintahan pusat. Inovasi dan kreativitas daerah sangat dituntut untuk memajukan daerahnya agar mampu bersaing di luar dan bersinergi dengan tujuan penyelenggaraan pemerintahan pusat. Saat ini perkembangan era digitalisasi pun ikut serta memengaruhi penyelenggaraan pemerintahan, di mana segala aktivitas kerja ataupun administrasi kerja pemerintahan dapat dilakukan melalui suatu sistem teknologi.

Pemerintah Provinsi Jambi saat ini melakukan suatu inovasi dalam penyelenggaraan pemerintahan melalui Badan Kepegawaian Provinsi Jambi dengan meluncurkan sebuah aplikasi penilaian prestasi pegawai berbasis website yang disebut dengan Sasaran Kinerja Pegawai (SKP)-Online yang bisa diakses melalui internet dengan alamat di http://skp. Jambiprov.go.id. Pelaksanaan penilaian prestasi kerja pegawai melalui aplikasi SKP-Online diatur di dalam Peraturan Gubernur Nomor 5 Tahun 2018 tentang Tambahan Penghasilan Pegawai Negeri Sipil di Lingkungan Pemerintah Provinsi
Jambi dan Peraturan Gubernur Nomor 5 Tahun 2019 tentang Pedoman Penilaian Kinerja Dalam Pemberian Tambahan Penghasilan Pegawai Negeri Sipil dan Calon Pegawai Negeri Sipil di Lingkungan Pemerintah Provinsi Jambi. SKP-Online mulai disosialisasikan pada pertengahan tahun 2018 dan diberlakukan secara keseluruhan mulai tahun 2019. SKPOnline diatur di dalam peraturan tersebut dikarenakan penerapan SKP-Online berkesinambungan dengan pemberian Tambahan Penghasilan Pegawai (TPP) yang akan diterima oleh pegawai setiap bulannya.

SKP-Online di Provinsi Jambi dilaksanakan secara periodisasi, di mana setiap bulannya pegawai wajib melakukan penginputan data laporan kinerja yang dilakukannya selama satu bulan sesuai dengan ketentuan yang telah diatur. Namun dengan berlakunya penerapan SKP-Online saat ini masih terdapat beberapa kendala yang terjadi di lapangan salah satunya seperti di Biro Umum Sekretariat Daerah Provinsi Jambi yang dalam hal ini menjadi lokus penelitian yang dipilih oleh penulis. Penerapan SKP-Online di lingkungan Biro Umum Setda Provinsi Jambi masih belum berjalan secara optimal sehingga masih diragukan keefektifannya dalam meningkatkan kinerja pegawai secara menyeluruh. 
KendalayangterjadipadapenerapanSKPOnline ialah masih kurangnya pemahaman pegawai tentang cara penginputan laporan realisasi kinerja bulanan melalui aplikasi SKP-Online, sehingga penerapannya belum berjalan efektif. Hal ini terlihat dari banyaknya pegawai yang tidak menguasai teknologi terutama penggunaan komputer dan internet bagi para pegawai yang sudah memasuki usia lanjut dan mendekati pensiun. Adapun data pegawai di lingkungan Biro Umum berdasarkan usia dan pendidikan sebagaimana tampak pada tabel 1 .

Pada tabel 1 terlihat rentang usia pegawai yang ada di lingkungan Biro Umum Setda Provinsi Jambi, di mana rentan usia 51-58 tahun merupakan jumlah terbanyak di Biro Umum dengan jumlah 32 orang pegawai. Hal inilah yang menjadi masalah kurangnya pemahaman pegawai dalam penerapan SKP-Online yang berbasis sistem, sehingga banyaknya pegawai yang sulit untuk memahami cara pengoperasian dan penginputan data realisasi bulanannya dan memilih mengendalkan pegawai lain untuk melakukan penginputan realisasi kinerjanya melalui SKP-Online yang membuat kurangnya rasa tanggung jawab pegawai terhadap kewajibannya sebagai pegawai negeri sipil. Hal tersebut ditambah dengan kurangnya pengawasan pimpinan sehingga penyimpangan masih kerap terjadi dalam mengoptimalkan efektivitas penerapan SKP-Online di Lingkungan Biro Umum Setda Provinsi Jambi.

Berdasarkan latar belakang penulisan tersebut di atas, maka dapat dibuat perumusan masalahnya adalah bagaimana efektivitas penerapan Sasaran Kinerja Pegawai (SKP)-Online di Biro Umum Sekretariat Daerah Provinsi Jambi?

\section{TINJAUAN PUSTAKA}

Efektivitas pada umumnya dipandang sebagai tingkat pencapaian tujuan yang operatif dan operasional. Menurut Mutiarin dan Zaenudin (2014:95) "efektivitas berasal dari kata kerja efektif, berarti terjadinya suatu akibat atau efek dikehendaki dalam perbuatan". Sedangkan menurut Ravianto (2014:11) bahwa "Pengertian efektivitas ialah seberapa baik pekerjaan yang dilakukan, sejauh mana orang menghasilkan keluaran sesuai dengan yang diharapkan".

Menurut Gibson dkk dalam Pasolong (2013:4) "Efektivitas adalah pencapaian sasaran dari upaya bersama". Selanjutnya Gibson, Donnelly, dan Ivancevich (1984) memberikan batasan dalam memberikan kriteria efektivitas organisasi melalui pendekatan sistem, yaitu:

1. Produksi (production)

Produksi merupakan kemampuan organisasi untuk memproduksi jumlah dan mutu output yang sesuai dengan permintaan lingkungan

2. Efisiensi (efficiency)

Konsep ini didefinisikan sebagai angka perbandingan (rasio) antara output dan input. Ukuran efisiensi ini harus dinyatakan dalam perbandingan antara keuntungan dan biaya atau dengan waktu atau dengan output.

3. Kepuasan (satisfaction)

Memperhatikan keuntungan yang diterima oleh para pesertanya maupun para pelanggannya. Kepuasan dan semangat kerja adalah istilah yang serupa yang menunjukkan sampai seberapa jauh organisasi memenuhi kebutuhan karyawannya.

4. Adaptasi (adaptivenees)

Kemampuan adaptasi adalah sampai seberapa jauh organisasi dapat menanggapi perubahan intern dan ekstern. 


\section{Pengembangan (development)}

Organisasi harus menginvestasi dalam organisasi itu sendiri untuk memperluas kemampuannya untuk terus bertahan (survive) dalam jangka panjang. Usaha pengembangan yang biasa adalah program pelatihan bagi tenaga manajemen dan non-manajemen, tetapi sekarang ini pengembangan organisasi telah berkembang banyak macamnya dan meliputi sejumlah pendekatan psikologis dan sosiologis.

Adapun menurut G. Shabbir Cheema dan Denis A. Rondinell (1983) dalam Mutiarin dan Zaenudin (2014:98-99) ada empat faktor yang memengaruhi efektivitas, yaitu sebagai berikut.

1. Kondisi Lingkungan

2. Hubungan antarorganisasi

3. Sumber Daya organisasi untuk implementasi program

4. Karakteristik dan kemampuan agen pelaksana.

Teori atau aspek-aspek di atas merupakan rujukan penulis dalam penelitian ini yang digunakan sebagai tolak ukur untuk melihat efektivitas dari penerapan sasaran kinerja pegawai (SKP)-Online di lingkungan Biro Umum Sekretariat Daerah Provinsi Jambi.

\section{METODE PENELITIAN}

Metode yang digunakan dalam penelitian ini adalah metode kualitatif dengan pendekatan deskriptif. Penelitian menggunakan teknik purposive sampling dengan menentukan informan secara terstruktur dan teknik pengumpulan data dengan menggunakan teknik observasi, wawancara dan dokumentasi yang berhubungan dengan SKP-Online, serta teknik analisis data yang dilakukan dengan mereduksi data, penyajian dan dan penarikan simpulan.

\section{HASIL DAN PEMBAHASAN}

Efektivitas Penerapan Sasaran Kinerja Pegawai (SKP)-Online di Lingkungan Biro Umum Sekretariat Daerah Provinsi Jambi

Untuk melihat efektivitas penerapan SKP-Online di Biro Umum Setda Provinsi Jambi penulis menggunakan teori Gibson, Donnelly, Ivancevich (1984) mengenai lima dimensi kriteria efektivitas organisasi melalui pendekatan sistem, yaitu produktivitas, efisiensi, kepuasan, adaptasi dan pengembangan.

\section{Produktivitas}

Pelaksanaan SKP-Online dikatakan berhasil apabila kualitas dan kuantitas yang dihasilkan mengalami perubahan yang signifikan dan memuaskan, namun nyatanya kualitas kinerja pegawai masih rendah dilihat dari masih banyak pegawai yang belum memahami pelaksanaan penginputan realisasi kinerja melalui SKP-Online. Hal tersebut memengaruhi bagaimana cara atau proses penginputan realisasi kinerja pegawai melalui aplikasi SKPOnline, serta penilaian kuantitas yang rendah dengan tingkat ketidakdisiplinan pegawai yang masih tinggi dilihat dari rekapan data absensi pegawai pada 2019. Sehingga produktivitas kerja dengan penerapan SKP-Online yang ada di lingkungan Biro Umum masih rendah

\section{Efisiensi}

Pada pelaksanaan SKP-Online di Biro Umum Setda Provinsi Jambi perbandingan antara input dan output antarpegawai masih belum berjalan seimbang sesuai dengan realisasi kinerjanya. Dilihat dari pekerjaan yang diinput direalisasi kinerja melalui SKPOnline masih belum sesuai dengan apa yang sebenarnya dikerjakan oleh setiap pegawai. sehingga penerapan SKPOnline yang berkesinambungan dengan 
tambahan penghasilan pegawai (TPP) dapat dikatakan belum efisien.

\section{Kepuasan}

Penerapan SKP-Online mendapatkan respons positif dari pegawai karena didukung dengan adanya kenaikan besaran TPP pegawai sebesar $20 \%$. dan saat penelitian berlangsung bersamaan dengan adanya wabah pandemic covid-19 yang menyebabkan pegawai melaksanakan pekerjaannya dari rumah atau work from home (WFH) sehingga untuk penilaian dari kedisiplinan absensi kehadiran menggunakan finger print ditiadakan dan diganti dengan absensi manual. kelonggaran terhadap absensi tersebut berdampak pada pemberian TPP yang memungkinkan tidak ada pemotongan

\section{Adaptasi}

Kebiasaan lama atau mindset pegawai masih belum dapat menyesuaikan perubahan sistem sehingga berdampak dengan adanya penerapan SKP-Online, ditambah kurangnya pengetahuan dalam pengoperasian sarana dan prasaranayang ada untuk penerapannya serta kurangnya rasa tanggung jawab pegawai terhadap tupoksinya sebagai pegawai negeri sipil. Oleh karena itu dapat disimpulkan bahwa pegawai masih belum bisa beradaptasi dengan perubahan yang terjadi, yaitu adanya penerapan SKP-Online dalam penilaian prestasi kerja pegawai yang berkesinambungan dengan pemberian TPP.

\section{Pengembangan}

Motivasi pegawai untuk meningkatkan kualitas kerja masih belum terasa, ditambah kurangnya dukungan dari lingkungan kerja untuk lebih bertanggung jawab atas tupoksinya. Sehingga masih perlu upaya untuk mengefektifkan pelaksanaan kerja dan menghargai kinerja pegawai.
Dari penjelasan kelima dimensi di atas, dapat disimpulkan bahwa efektivitas penerapan SKP-Online di Biro Umum masih belum berjalan secara optimal. oleh sebab itu masih perlu dilakukan suatu inovasi intern organisasi agar pegawai mampu beradaptasi dengan perkembangan zaman saat ini. Hal yang dapat dilakukan seperti memberikan pendidikan dan pelatihan, pemberian motivasi, penghargaan serta ketegasan juga dorongan dari pimpinan agar mampu dalam mengimplementasikan "Revolusi Mental" untuk keberhasilan suatu kebijakan atau penerapan suatu sistem

\section{Faktor Penghambat Dalam Penerapan Sasaran Kinerja Pegawai (SKP)-Online di Lingkungan Biro Umum Sekretariat Daerah Provinsi Jambi}

Setelah penulis melakukan wawancara dengan tim verifikatur di BKD Provinsi Jambi dan beberapa informan lainnya yang berasal dari Biro Umum Setda Provinsi Jambi dapat digaris bawahi bahwa faktor-faktor yang menghambat efektivitas dari penerapan SKP-Online di antaranya sebagai berikut.

\section{Lingkungan Kerja}

Lingkungan kerja yang masih menganggap enteng penilaian prestasi kerja pegawai sehingga penerapan SKPOnline tidakmemengaruhisikap perilaku pegawai untuk bertanggung jawab atas kewajibannya sebagai pegawai negeri sipil dalam meningkatkan kualitas dan kuantitas kinerja secara optimal.

\section{Sumber Daya Manusia}

Kesiapan SDM dalam pelaksanaan penerapan SKP-Online yang tidak didukung dengan motivasi pegawai untuk melakukan pengembangan diri dalam memperbanyak pengetahuan atau belajar agar dapat mengoperasikan penginputan data realisasi kinerjanya sendiri. Sehingga terdapat ketidakpahaman pegawai tentang bagaimana pengoperasian aplikasi SKP- 
Online. Bahkan meminta tolong orang lain untuk menginput tugasnya dalam pelaporan realisasi kinerja melalui SKPOnline.

\section{Pengawasan dan Ketegasan Pimpinan}

Minimnya pengawasan dan ketegasan atasan atau pimpinan menyebabkan lemahnya kompetensi pegawai untuk mengembangkan diri agar bekerja lebih produktif. Sanksi yang adapun tidak memberikan efek jera terhadap sikap perilaku pegawai sehingga penyimpangan masih kerap terjadi dalam mengefektifkan penerapan SKP-Online.

\section{Upaya yang Dilakukan Untuk Meningkatkan Kinerja Pegawai Dalam Penerapan SKP-Online di Lingkungan Biro Umum Sekretariat Daerah Provinsi Jambi}

1. Membuat suatu inovasi dengan membentuk grup pegawai Biro Umum Setda Prov. Jambi dalam suatu aplikasi

2. Melakukan sosialisasi kembali kepada seluruh pegawai di lingkungan Biro Umum Setda Prov. Jambi, dengan adanya tutorial pengoperasian SKP-Online

3. Memotivasi kembali para pegawai agar mau belajar cara penggunaan sarana teknologi

Keseluruhan upaya yang dilakukan sebetulnya sudah cukup bagus. Hanya saja seiring berjalannya waktu upaya tersebut tidak sepenuhnya berhasil meningkatkan kinerja pegawai dalam penerapan SKPOnline. karena upaya tersebut masih belum menunjukkan dampak yang signifikan dalam membangun rasa tanggung jawab pegawai terhadap tupoksinya dan peningkatan kedisiplinan kerja. Oleh karena itu masih perlu adanya upaya lain yang lebih tegas dan berdampak signifikan untuk mencapai tujuan dari penerapan SKP-Online, sehingga pemberian TPP lebih efisien dan mampu meningkatkan kualitas kerja pegawai secara optimal serta menciptakan lingkungan kerja yang berkompeten

\section{SIMPULAN}

Berdasarkan hasil penelitian dan pembahasan, dapat disimpulkan bahwa Efektivitas Penerapan SKP-Online di Biro Umum Setda Provinsi Jambi dapat dikatakan belum berjalan dengan baik dan optimal dari proses pelaksanaannya dan pengawasan dalam penerapannya. Hal tersebut dapat dilihat dari indikator Produktivitas, Efisiensi, Kepuasan, Adaptasi dan Perkembangan oleh Gibson, Donnelly, Ivancevich (1984), bahwa dari kelima dimensi tersebut bila dibandingkan dengan realita di lapangan masih belum berjalan seimbang sesuai dengan definisinya. Karena pada penerapan SKP-Online dimensi yang menonjol hanyalah dari dimensi kepuasan dikarenakan adanya kenaikan besaran TPP pegawai sebesar 20\%. Sedangkan secara real di lapangan dimensi lainnya belum mendukung keefektifan penerapan SKP-Online di Biro Umum Setda Provinsi Jambi.

Beberapa faktor yang menjadi penghambat dalam efektivitas Penerapan SKP-Online ialah sebagai berikut.

1. Lingkungan Kerja, yang masih menunjukkan sikap perilaku pegawai yang belum bertanggung jawab sepenuhnya atas kewajibannya sebagai pegawai negeri sipil dalam meningkatkan kualitas dan kuantitas kinerja secara optimal

2. Sumber Daya Manusia, yang belum menunjukkan kesiapan dalam perkembangan zaman dan perubahan sistem kerja sehingga masih mengendalkan orang lain dalam penginputan realisasi kinerjanya melalui SKP-Online.

3. Pengawasan dan Ketegasan Dari Pimpinan yang masih rendah, menyebabkan kurangnya motivasi pegawai dan lemahnya kompetensi 
pegawai untuk mengembangkan diri agar bekerja lebih produktif

Adapun upaya yang dilakukan untuk meningkatkan kinerja pegawai dalam penerapan SKP-Online di antaranya sebagai berikut.

1. Membuat suatu inovasi dengan membentuk grup pegawai dalam satu aplikasi;

2. Melakukan sosialisasi kembali kepada seluruh pegawai dan menginformasikan adanya tutorial pengoperasian SKPOnline;

3. Memotivasi pegawai agar mau belajar cara penggunaan sarana teknologi.

\section{SARAN}

Dari Simpulan yang telah diuraikan di atas, berikut beberapa saran dalam penelitian ini, yaitu; (1) Pada dasarnya penerapan SKPOnline di Biro Umum Setda Provinsi Jambi masih belum terlaksana sesuai ketentuan yang berlaku. Sehingga perlu diperhatikan kembali untuk penilaian prestasi kerja pegawai melalui SKP-Online dilakukan sesuai poin-poin yang telah ditentukan yang tercantum pada peraturan perundangan yang berlaku, (2) Pejabat penilai dalam menilai pegawai atau bawahannya harus objektif, terukur, akuntabel, partisipatif dan transparan sehingga nilai yang didapat sesuai dengan kinerjanya, (3) Biro umum Setda Provinsi Jambi perlu membuat satu kegiatan yang menunjang dalam meningkatkan kapasitas aparatur dengan memberikan pelatihan khusus di bidang TIK, (4) Perlu adanya kritik atau evaluasi dalam penerapan SKP-Online di Pemerintah Provinsi Jambi agar dapat dilaksanakan sesuai mekanisme yang berlaku.

\section{DAFTAR PUSTAKA}

Arikunto, Suharsimi. 2010. Prosedur Penelitian, Rineka Cipta, Jakarta

Creswell, John W. 2018. Research Design Pendekatan Metode Kualitatif, Kuantitatif, dan Campuran) Pustaka Pelajar, Yogyakarta.

Gibson, J. L, Ivancevich, J. M dan Donnelly, J. Jr. 1984. "Organisasi dan Manajemen": Perilaku, Struktur dan Proses, Erlangga, Jakarta.

Hasibuan, Malayu S. P. 2009. Manajemen Sumber Daya Manusia, Bumi Aksara, Jakarta.

Makmur. 2011. Efektivitas Kebijakan Kelembagaan Pengawasan, Refika Aditama, Bandung.

Mutiarin, Dyah dan Arif Zainudin. 2014. Manajemen Birokrasi dan Kebijakan, Pustaka Pelajar, Yogyakarta.

Ndraha, Taliziduhu. 2011. Kybernology (Ilmu Pemerintahan Baru) 1, Rineka Cipta, Jakarta.

Ravianto, J. 2014. Produktivitas dan Pengukuran, Binaman Aksara, Jakarta.

Rivai, Veithzal. 2011. Manajemen Sumber Daya Manusia untuk Perusahaan Dari Teori ke Praktik, Rajawali Press, Jakarta.

Sedarmayanti. 2017. Sumber Daya Manusia dan Produktivitas Kerja, Mandar Maju, Bandung.

Silalahi, Ulber. 2010. Metodologi Penelitian Sosial. Bandung: Refika Aditama.

Steers, M. Richard. 1985. Efektivitas Organisasi, Erlangga, Jakarta.

Tyson, S dan Jackson, T. 1992. Perilaku Organisasi, Andi, Yogyakarta.

Wibowo. 2014. Manajemen Kinerja, Rajawali Pers, Jakarta.

Zuriah, Nurul. 2009. Metodologi Penelitian Sosial dan Pendidikan, Bumi Aksara, Jakarta

\section{Peraturan Perundang-Undangan}

Peraturan Kepala Badan Kepegawaian Negara Nomor 1 Tahun 2013 tentang Ketentuan Pelaksanaan Peraturan Nomor 46 Tahun 2011 tentang Penilaian Prestasi Kerja Pegawai Negeri Sipil

Peraturan Gubernur Nomor 5 Tahun 2019 tentang Pedoman Penilaian Kinerja Dalam Pemberian Tambahan Penghasilan Pegawai Negeri Sipil dan Calon Pegawai Negeri Sipil di Lingkungan Pemerintah Provinsi Jambi 